\title{
Role of lipoproteins in the formation of spur cell anaemia
}

\author{
MANUEL MARTINEZ-MALDONADO
}

\author{
From the Medical Service, San Juan Veterans Administration Hospital and the Department of \\ Medicine, University of Puerto Rico School of Medicine, San Juan, Puerto Rico
}

SYNOPSIS The case of a patient with cirrhosis of the liver suffering from severe haemolysis accom:panied by circulating 'spur cells' is described. Studies performed in an attempt to determine the cause for the abnormal shape of the erythrocytes demonstrated that the patient's serum could induce sput formation in normal compatible cells. Several lines of evidence pointed to the possibility that the factor inducing the spurs was a protein. By column chromatography and gradient ultracentri fugation it was shown that the patient's low density lipoproteins could induce spurs to form normal cells.

In 1964, Smith, Lonergan, and Sterling first described a syndrome consisting of bizarrely shaped erythrocytes associated with intense haemolytic anaemia in a young man with hepatic cirrhosis. They termed this syndrome 'spur cell anaemia'. Since then one more case has been reported in detail (Silber, Amorosi, Lhowe, and Kayder, 1966), and seven others have been briefly described (Grahn, Díetz, and Stefani, 1966). Excluding the report of Silber et al (1966), in all cases incubation of the patient's serum with normal compatible erythrocytes induced spur-like deformities in the cells. This effect persisted when serum was dialysed (Smith et al, 1964; Grahn et al, 1966) suggesting that a protein or protein-bound substance was responsible for the changes induced in the erythrocytes. The purpose of the present report is to describe another case in which liver cirrhosis coexisted with spur cells and severe haemolysis. In addition, it is demonstrated that spur cells could be produced in vitro by incubating normal cells with a fraction of the patient's serum which contained low density lipoproteins.

\section{CASE REPORT}

A 42-year-old white man was admitted to the San Juan Veterans Administration Hospital on 19 January, 1962, because of anorexia, nausea without vomiting, jaundice of three months' duration, and the development of

Request for reprints should be addressed to: The Department of Medicine, Houston V.A. Hospital, Houston, Texas 77031.

Received for publication 19 October 1967. profuse bleeding following a tooth extraction. HQ⿱中⿰㇀丶㇀ urine had become dark brown two days before ad mission. Upon questioning, the patient admitted drinkiro one to two quarts of rum daily for the past six months and to 'heavy' drinking for the previous five years.

On admission, physical examination was as follows. blood pressure $130 / 80 \mathrm{~mm} \mathrm{Hg}$; pulse, 96/min; temperă ture, $98.6^{\circ} \mathrm{F}$; and weight, 170 pounds. The sclerae were jaundiced, and there was blood on the gums and teet The liver was felt 4 to $5 \mathrm{~cm}$ below the right costal mas= gin, but the spleen was not palpable. There was $\vec{r}$ ascites or oedema. Multiple spider angiomata were noted on the chest and back.

Laboratory studies showed: haemoglobin, $11.8 \mathrm{~g} / 10$ $\mathrm{ml}$; haematocrit, $39 \%$ white blood cell count, 7,650 per. $\mathrm{cu} \mathrm{mm}$ with a normal differential and normal platelef count. Routine coagulation studies were normal. Tot serum bilirubin was $4.6 \mathrm{mg} / 100 \mathrm{ml}$ with a direct reactiog fraction of $1.4 \mathrm{mg} / 100 \mathrm{ml}$. Serum glutamic oxalacet transaminase, $116 \mathrm{u}$ : serum glutamic pyruvic trans minase, $44 \mathrm{u}$; lactic dehydrogenase, $330 \mathrm{u}$; alkaline phosphatase, 10 Shinowara-Jones-Reinhart units (no mal 2 to 9); serum cholesterol, $260 \mathrm{mg} \%$ with 54 罗 esters. Prothrombin time was $17 \mathrm{sec}$ with a control \&: 12 seconds. A bromsulphalein excretion test showed reg retention of $14.8 \%$ after 45 minutes. A chest radiograph and barium swallow were negative.

No further bleeding occurred from the gums and the patient improved. He was discharged on 15 Februagy 1962, with a diagnosis of Laennec's cirrhosis of the liver.

He was readmitted on 6 April 1963, with complain similar to those on his previous admission. Although 19 had carefully watched the colour of his urine, he had not noticed any change until 10 days before admission, when it again became dark. At that time he had been on drinking spree during which he drank from two to two and a half quarts of rum daily. He denied ang 620 
change in the colour of his stool. Examination revealed marked icterus of all mucous membranes and skin. The liver was felt four fingerbreadths below the right costal margin; the tip of the spleen was palpable. There was ascites. Examination was otherwise similar to the one during his first admission.

Laboratory examinations: haemoglobin, $9.9 \mathrm{~g} / 100 \mathrm{ml}$; haematocrit, $31 \%$; red blood cells, 3.29 millions cu mm, and white blood cells, 9,950 cu mm, with a normal differential count. On several occasions, numerous acanthocyte-like cells were seen in peripheral blood smears. Urine analysis was normal. Total serum bilirubin was $10.8 \mathrm{mg} / 100 \mathrm{ml}$ with $4.1 \mathrm{mg} / 100 \mathrm{ml}$ direct-reacting bilirubin. Prothrombin time was $24 \mathrm{sec}$ with a control of 13 seconds. Serum albumin, $3.2 \mathrm{~g} / 100 \mathrm{ml}$; serum globulin, $5 \cdot 3 \mathrm{~g} / 100 \mathrm{ml}$. Cephalin flocculation test was $4+$ in 48 hours. Serum enzyme determinations were as follows: SGOT, $58 \mathrm{u}$; SGPT, $26 \mathrm{u}$; alkaline phosphatase, 13.6 SJR u. Total serum cholesterol was $347 \mathrm{mg} / 100 \mathrm{ml}$, and total serum lipids $403 \mathrm{mg} / 100 \mathrm{ml}$. Serum $\beta$-lipoproteins were normal. Stools were repeatedly Guaiac negative.

${ }^{51}$ Chromium tagged red blood cells showed a half-life of 13 days (normal $=30 \pm 3$ days) with a predominant uptake of radioactivity over the spleen. Urine urobilinogen was 3.76 Ehrlich units in 24 hours. Faecal urobilinogen was 610 Ehrlich units in 24 hours. Reticulocyte counts ranged from $0.9 \%$ to $7 \cdot 3 \%$. Coombs and cold agglutinin tests were repeatedly negative. The patient was given diuretics and was placed on bed rest. On this occasion, a barium swallow showed prominent oesophageal varices. Improvement was slow, but the decrease in serum bilirubin level fell definitely. By 28 May 1963, there had been a decrease in the reticulocyte count, the spleen was not palpable, and the haemoglobin had risen to $11.0 \mathrm{~g} / 100 \mathrm{ml}$. The patient was discharged to be seen as an outpatient but did not return until 6 May 1964 for his third and last admission. He admitted to having drunk over one to one and a half quarts of rum daily for the previous three months. There was marked ascites and oedema as well as jaundice. Neither the liver nor the spleen were palpable. Once more numerous spur cells were seen in the blood smears. Liver function tests were abnormal as on the previous admission and essentially unchanged. Direct and indirect Coombs and cold agglutinins tests were negative. Table I summarizes the results of some of the laboratory results during this final period in hospital.

On several occasions he developed episodes of hepatic precoma which responded to treatment with Glutavene-K, oral neomycin sulphate, and intravenous infusions of glucose. Apart from occasional periods of lucidity, the patient did very poorly. On 3 August 1964 he developed high fever and hepatic coma. Examination revealed leftsided bronchopneumonia. Severe acidosis developed and in spite of treatment the patient expired on 5 August 1964.

POST-MORTEM FINDINGS Marked icterus of skin and mucous membranes was noted. There were large oesophageal varices. The abdominal cavity contained 1,700 $\mathrm{ml}$ of yellowish ascites fluid. Although the spleen was markedly enlarged (weight, $660 \mathrm{~g}$ ), it did not extend below the costal margin. Histological examination of this organ revealed marked congestion and haemorrhage of the red pulp. The liver was nodular and weighed 1,100 grams. Histologically there were few fatty changes but a severe postnecrotic type of cirrhosis was present.

\section{SPECIAL STUDIES}

In an attempt to determine the cause of the abnormal shape of the red cells, the following studies were done. Incubation of compatible normal red cells, and those of a cirrhotic patient with the patient's plasma at $37^{\circ} \mathrm{C}$ for one to six hours caused the formation of spur cells in both instances (Fig. 1). These were observed in both 'dry' and 'wet' smears of the erythrocytes. In contrast, normal and icteric plasma from another patient failed to produce the defect in normal compatible cells. These two procedures were repeated on several occasions with identical results. The patient's plasma retained its capacity to produce spurs after freezing

TABLE I

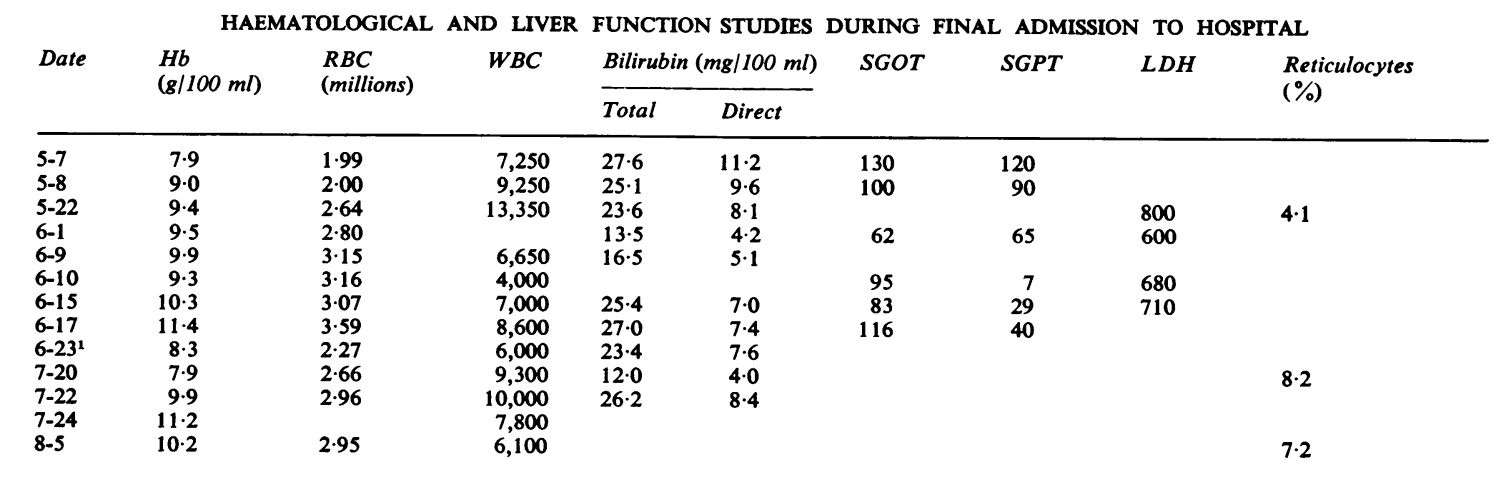

${ }^{1} \mathrm{Cr}^{51} \mathrm{~T}_{1 / 2} \mathrm{RBC}$ survival 6-22-64; 11 days $(\mathrm{N}=30 \pm 3$ days). 


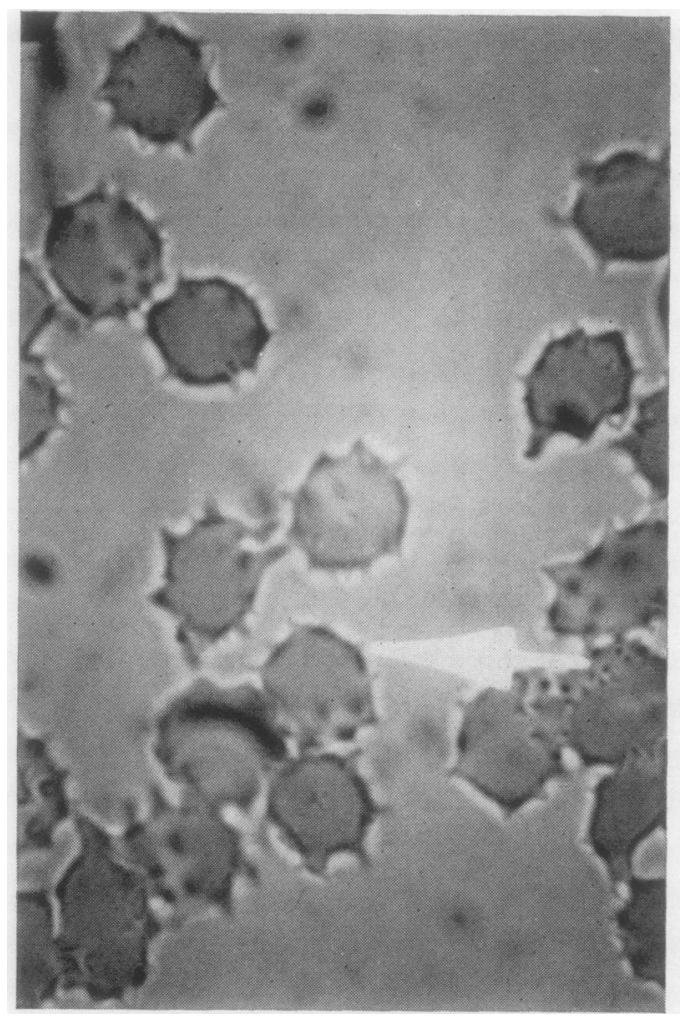

FIG. 1. Spur-cells. Oil immersion, dry smear.

and thawing. Dialysis of the plasma at room temperature for 24 hours did not inhibit its capacity to induce spurs. As in the experience of others (Smith et al, 1964), the dialysate possessed no activity whatever. Serum that had been kept frozen for six months retained its spur-forming capacity.

To further elucidate the nature of the spurproducing substance, fractionation of the serum was performed using Sephadex G-200 following the procedure described by Rivera, Toro-Goyco, and Matos (1965). A fractionation pattern similar to that reported by these investigators for other cirrhotic patients was obtained (Fig. 2). A serum protein chromatograph utilizing Sephadex G-200 gives three protein fractions. Fraction A contains 19 S globulins, fraction B, $7 \mathrm{~S}$ globulins, while fraction $\mathrm{C}$ contains the albumin. Although there was a normal amount of $19 \mathrm{~S}$ globulins (peak A), a marked increase in $7 \mathrm{~S}$ globulins (peak B) and a low albumin peak (peak C) were noticed. A pool of the fractions corresponding to each of the three protein peaks was made. Each fraction was lyophilized and the material so obtained suspended in $1 \mathrm{ml}$ of normal saline. A clear solution was

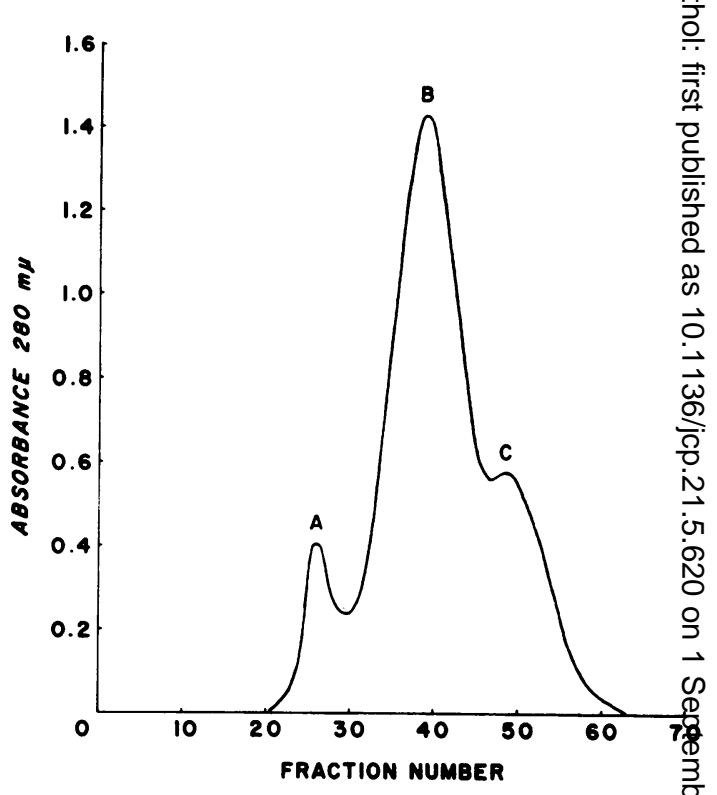

FIG. 2. Sephadex G-200 chromatogram of serum protei贷

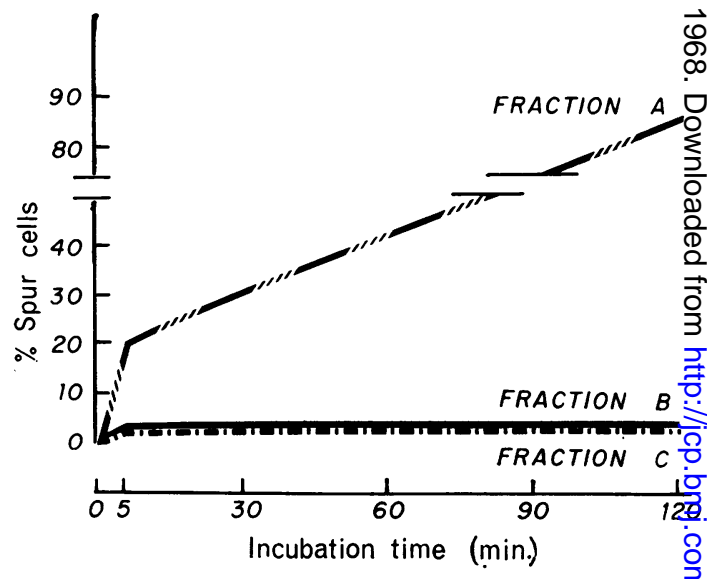

FIG. 3. Incubation of normal compatible erythrocytes with protein fractions obtained from Sephadex G-200 sieving.

obtained from the material corresponding to pro tein peaks B and C. A slightly cloudy, whitiste suspension was obtained from the material corresponding to peak $A$. This was centrifuged and the supernatant utilized. One half millilitre of each of these solutions, representing peaks $\mathrm{A}, \mathrm{B}$, and $\mathrm{C}$ 通 the chromatogram, was incubated with $0.5 \mathrm{ml}$ of normal cells compatible with the patient's origina blood for two hours. One drop of each incubated sample was examined at five minutes and at tw hours after the incubation was started. On bo occasions no activity was found in the mixture corresponding to peak $\mathrm{C}$ and only an occasion 


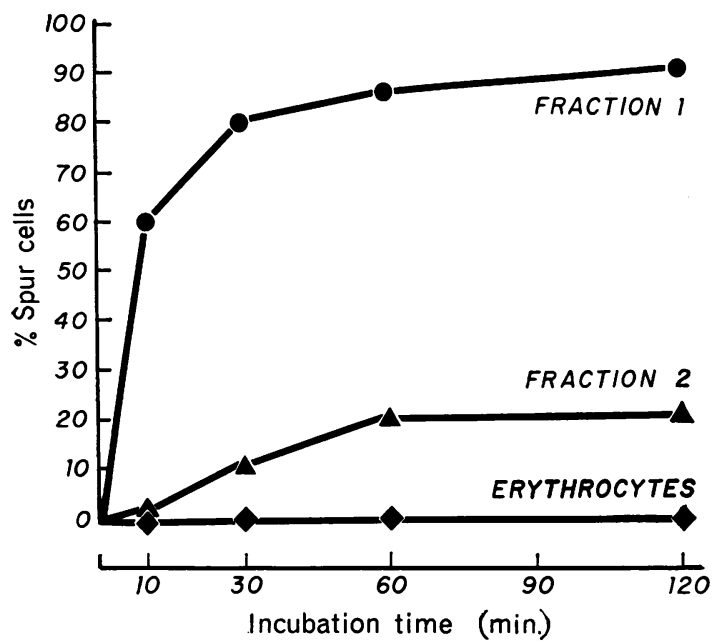

FIG. 4. Incubation of normal compatible erythrocytes with lipoprotein fractions obtained from concentration gradient ultracentrifugation.

cell with spurs was seen in the mixture corresponding to peak B. In mixture A, $20 \%$ of the cells at $5 \mathrm{~min}$ and $85 \%$ at two hours showed spurs (Fig. 3), strongly suggesting that the cause of the defect was a macroglobulin or a macroglobulin-bound compound.

To further identify the protein responsible for the formation of spurs, the following experiment was carried out.

A sodium chloride solution with a density of $1.30 \mathrm{~g}$ per $\mathrm{ml}$ was placed in a $5 \mathrm{ml}$ lusteroid tube $(1 \times 5 \mathrm{~cm})$. Two $\mathrm{ml}$ of the patient's serum was layered over the saline. After this $1 \mathrm{ml}$ of sodium chloride solution with a density of $1.005 \mathrm{~g}$ per $\mathrm{ml}$ was layered over the serum. This preparation was centrifuged in a swinging bucket rotor (SW 39) in a Spinco preparative ultracentrifuge for 18 hours at $105,000 \mathrm{~g}(40,000 \mathrm{cpm})$. After this time the tube was carefully removed to avoid mixing of the phases. One $\mathrm{ml}$ of the superiormost phase containing the low density liproproteins was removed (fraction 1) as well as $1 \mathrm{ml}$ of the lower phase containing the rest of the serum proteins (fraction 2). Each fraction was dialyzed against $0.9 \% \mathrm{NaCI}$ for 18 hours before the incubation experiment. One-half $\mathrm{ml}$ of each protein fraction so obtained was incubated with $0.5 \mathrm{ml}$ of normal compatible erythrocytes at $37^{\circ} \mathrm{C}$. Erythrocytes alone were also incubated. One drop samples of each mixture were examined at $0,10,30,60$, and 120 minutes of incubation (Fig. 4). At zero minutes no spur cells were present. At 10 minutes from 0 to $1 \%$ of the cells (300 cells) incubated with fraction 2 were spurred while 60 to $70 \%$ of the cells incubated with fraction 1 showed the defect. At 30,60 , and 120 minutes, 10 to $20 \%$ of the cells in fraction 2 and 80 to $90 \%$ of the cells in fraction 1 showed spurs. At no time did the erythrocytes incubated alone show any spurs. It was concluded from this that a low density lipoprotein was the main cause of the spur forming in the red cells.

It has been reported (Smith et al, 1964; Sterling, Rose, Smith, and Lonergan, 1964) that red blood cell cholesterol is raised in spur-cell anaemia. In order to see if our patient also exhibited this feature, erythrocyte cholesterol (total and free) and percentage of esterification were determined in this patient by Dr Marta Cancio, utilizing a modification of the method of Zak (1957). Table II presents the normal values for our laboratory and the results in our patient, in two patients with uncomplicated liver cirrhosis, and in a patient with haemolytic anaemia. It is of interest that, although the plasma cholesterol values were within normal values, a marked decrease in both total and free cholesterol was present in the erythrocytes of our patient. By contrast, in two other cirrhotic patients and in one patient with acquired haemolytic anaemia utilized as controls, these values were normal.

\section{DISCUSSION}

The present studies are in accord with the original suggestion of Smith et al (1964) that a protein may be the cause of spur-cell formation in cirrhotics. More specifically, as has been shown to be the case

TABLE II

PLASMA AND ERYTHROCYTE CHOLESTEROL STUDIES

\begin{tabular}{|c|c|c|c|c|c|c|}
\hline & \multicolumn{3}{|l|}{ Plasma } & \multicolumn{3}{|c|}{ Erythrocytes } \\
\hline & Total & Percentage Esters & Free & Total & Percentage Esters & Free \\
\hline $\begin{array}{l}\text { Normal }(\mathrm{mg} / 100 \mathrm{ml}) \\
\text { Range } \\
\text { Mean } \\
\text { Patient } \\
\text { Cirrhotic } 1 \\
\text { Cirrhotic } 2 \\
\text { Haemolytic anaemia }\end{array}$ & $\begin{array}{l}145-276 \\
219 \\
198 \\
176 \\
254 \\
114\end{array}$ & $\begin{array}{l}58-85 \\
73 \\
52 \\
74 \\
85 \\
66\end{array}$ & $\begin{array}{l}28-103 \\
61 \\
32 \\
46 \\
42 \\
39\end{array}$ & $\begin{array}{l}143-213 \\
171 \\
107 \\
184 \\
157 \\
158\end{array}$ & $\begin{array}{c}9-30 \\
17 \\
20 \\
6 \\
23 \\
4\end{array}$ & $\begin{array}{c}115-192 \\
144 \\
86 \\
174 \\
121 \\
151\end{array}$ \\
\hline
\end{tabular}


in the present study, low density lipoproteins can lead to alterations in the shape of the cell membrane and therefore to haemolysis. Evidence that abnormalities in serum lipoproteins may lead to haemolysis has been recently advanced by Ways (1967). He has demonstrated that abnormal increments in plasma lipids arising from deranged liver function can alter erythrocyte membrane lipid composition and survival in vivo. Unfortunately, no description of the red cell morphology of the studied case is given.

Although low density lipoproteins are obviously the main cause of the spurs forming under the conditions of our experiment, the fact that the lowermost layer from the ultracentrifugation experiments produced spurs in 10 to $20 \%$ of the incubated cells suggests that other proteins may cause the defect. In fact, Grahn et al (1966) were able to induce changes in the shape of red cells by incubating normal erythrocytes with the albumin fraction of three of their seven patients with spurcell anaemia. Whether qualitative changes in protein structure or alterations in the normal relationship between serum and erythrocyte proteins are responsible for inducing the changes remains to be elucidated.

Because of the circumstances under which our experiments were performed (only 3.5 to $5.0 \mathrm{ml}$ of plasma was available for study) further elucidation of the role played by other proteins and more precise characterization of the low density lipoproteins could not be carried out. The overwhelming difference between fractions 1 and 2 (see Fig. 4), however, leave no doubts as to the primordial role of the low density lipoproteins in producing spur cells in the present case.

The failure of Silber et al (1966) to demonstrate spur cells when serum from their patient was incubated with normal compatible cells deserves comment. It seems possible that this particular patient represents an entity different from the one described presently and that described by Smith et al (1964) and Grahn et al (1966). On the other hand, it is also possible that other factors not readily identifiable may also induce spur cells in cirrhotics. Although no particular effort has been made to determine the incidence of spur cells in cirrhosis, extensive and detailed studies of the anaemia seen in this disease (Jandl, 1955; Kimber, Deller, Ibbotson, and Lander, 1956) have failed to describe either the morphological abnormality or the degree of haemolysis presented by the patients so far described. The possibility raised by Silber and his colleagues that the passage of the cells through the arteriovenous shunts known to be present in liver cirrhosis may be the cause of spur cells seems highly unlikely. If this were the case, in view of the almost universal presence of these shunts in cirrhotics (Silverstein, 1956), one would expect the incidence of spur cells in cirrhosis to be higher than so far appreciated. It is possible that under special circumstances high flow rates through these shunts might lead to erythrocytic morphologica $\mathbb{D}$ changes; however, one would expect these changes to resemble closer the ones seen in micros angiopathic haemolytic anaemia (Brain, Dacie, and $\overrightarrow{6}$ Hourihane, 1962). At this time, however, in view of the fact that all other conditions that may lead tow abnormal cell shape were carefully eliminated by Silber and his collaborators no reasonable answe? is presently on hand. Further studies in search of spur cells in cirrhotic patients are therefore indicated. Clearly, other factors that may lead to 'burr' celf formation must be carefully sought before the diagnosis of spur cell anaemia in cirrhosis is established.

Although Sterling and his associates (1964) showed a marked increase in erythrocyte cholestero in a patient with spur-cell anaemia, they were able to observe the anomaly in cell shape even when red. cell cholesterol was normal, and therefore, discardedthe possiblity that excess cholesterol in the celpo was responsible for the spur formation. Our findings of a low erythrocyte cholesterol content support this view. In addition, in a number of diseases as high erythrocyte cholesterol content has been found without abnormalities in the normal shape of the erythrocytes (Brun, 1939).

The morphological similarity between spur cells and the acanthocytes seen in congenital absence o $\bar{\beta}$ $\beta$-lipoproteins (Salt, Wolff, Lloyd, Fosbrooke? Cameron, and Hubble, 1960; Bassen and Kornz? weig, 1950) makes it necessary to differentiat between the two conditions. In view of the absence of neurological disorders, retinitis pigmentosa, and malabsorption syndrome and the presence of nor: mal serum $\beta$-lipoproteins, the possibility that oug patient suffered from the syndrome described by Bassen and Kornzweig (1950) may be discarded. In addition, the massive rate of haemolysis seen in our patient is in contradistinction to the smalf haemolysis in vivo observed in abetalipropros teinaemia (Simon and Ways, 1964). No evidence of renal disease, gastrointestinal bleeding (Schwartł and Motto, 1949), or severe vascular disease (Braiñ et $a l, 1962)$ was observed in the present case and therefore they may all be excluded as causes for the abnormal shape of the erythrocytes.

Although investigations regarding erythrocyte energy metabolism and transport were not carriec out, it would appear reasonable to assume that th great degree of haemolysis was in part the resulf of increased removal of cells with altered mem $\cong$ 
branes from the circulation. The increased uptake or radioactive label over the spleen is evidence that this suggestion is correct.

Dr Marta Cancio supplied the data on erythrocyte cholesterol and performed such studies in our patient. Dr E. Toro-Goyco performed the ultracentrifugation of the serum and made invaluable suggestions.

\section{REFERENCES}

Bassen, F. A., and Kornzweig, A. L. (1950). Blood, 5, 381.

Brain, M. C., Dacie, J. V., and Hourihane, D. O. (1962). Brit. J. Haemat., 8, 358.

Brun, G. C. (1939). Acta med. scand., suppl. 99.

Grahn, E. P., Dietz, A. A., and Stefani, S. (1966). Clin. Res., 14, 435.
Jandl, J. H. (1955). J. clin. Invest., 34, 390.

Kimber, C., Deller, D. J., Ibbotson, R. N., and Lander, H. (1965). Quart. J. Med., 34, 33.

Rivera, J. V., Toro-Goyco, E., and Matos, M. L. (1965). Amer. J. med. Sci., 249, 371.

Salt, H. B., Wolff, O. H., Lloyd, J. K., Fosbrooke, A. S., Cameron, A. H., and Hubble, D. V. (1960). Lancet, 2, 325.

Schwartz, S. O., and Motto, S. A. (1949). Amer. J. med. Sci., 218, 563.

Silber, R. R., Amorosi, E., Lhowe, J., and Kayden, H. J. (1966). New Engl. J. Med., 275, 639.

Silverstein, E. (1956). J. Lab. clin. Med., 47, 513.

Simon, E. R., and Ways, P. (1964). J. clin. Invest., 43, 1311.

Smith, J. A., Lonergan, E. T., and Sterling, K. (1964). New Engl. J. Med., 271, 396.

Sterling, K., Rose, H. G., Smith, J. A., and Lonergan, E. T. (1964). J. clin. Invest., 43, 1235.

Ways, P. (1967). Ibid., 46, 1129.

Zak, B. (1957). Amer. J. clin. Path., 27, 583. 